\title{
Efficiency evaluation of rainwater quality modification by utilizing mixing method with surface water and groundwater
}

\author{
M. T. Haji Alizadeh, M. T. Ghaneian \& A. Motedayen \\ Department of Environmental Health Engineering, Faculty of Health, \\ Shahid Sadoughi University of Medical Sciences, Yazd, Iran
}

\begin{abstract}
Due to industrial development, lack of water resources on a global scale and increasing water demands in both rural and urban societies, quests for reviving water resources and finding reproducible ones have soared in recent years. Meanwhile, rainwater is one of the most accessible water resources in societies with high rainfall seasons which could be utilized as a sustainable and reproducible resource of water supply. Average amount of TDS (Total Dissolved Solids) in surface water is about $300 \mathrm{MgL}^{-1}$, while for ground water is usually more than $1000 \mathrm{MgL}^{-1}$. Rain water contains very low amount of TDS (0-10) $\mathrm{MgL}^{-1}$. Besides the biological effects of low TDS water on the body, problems of taste and odour are always being reported by consumers. Mixing rainwater with water from other resources with higher TDS is one of the proposed solutions to solve this problem. In this research, we at first try to gather information about acceptability of rainwater quality (taste, hardness etc.) by questionnaire from the inhabitant of villages in the study area. Results indicated that more than 85 percent of inhabitants were displeased with the water quality. Then samples were analyzed to obtain primitive amount of physicochemical parameters and mixed with water from surface and underground resources in 3 ratio $(1 / 10,2 / 10$ and $3 / 10$ ) to obtain the best ratio of mixing for providing water with optimum TDS and TH. After statistical analysis of data, 2/10 mixing ratio was picked as the optimum rate in this experiment. By utilizing $2 / 10$ mixing ratio with surface water $(\mathrm{S} / \mathrm{R})$, final TDS of rainwater was increased up to $(80-94) \mathrm{MgL}^{-1}$ and $\mathrm{TH}$ up to (73-89) $\mathrm{MgL}^{-1} \mathrm{Caco}_{3}$, While this value is about (121-159) $\mathrm{MgL}^{-1}$ for TDS,
\end{abstract}


besides (125-141) $\mathrm{MgL}^{-1} \mathrm{Caco}_{3}$ for $\mathrm{TH}$ by utilizing the same ratio of mixing with ground water $(\mathrm{G} / \mathrm{R})$.

Keywords: efficiency, evaluation, rainwater, quality, modification, mixing, TDS (total dissolved solids), $\mathrm{TH}$.

\section{Introduction}

The increasing consumption of water and lack of its resources in recent years lead water managers to find new resources of water. In this case finding new resources for water with a warranty becomes the goal of managers. Meanwhile we should utilize renewable resources for water supply to societies. Rainwater is one of the most available water resources in societies with high rainfall seasons. Rain water harvesting is one of the most familiar terms in recent years [1]. Rainwater harvesting is an excellent tool which, with proper use, could dramatically reduce the continual strain on watersheds. Rainwater harvesting is not only useful in rural areas, but also it can provide numerous benefits for urban ecosystems by managing storm water runoff [2]. Utilizing rainwater for indoor and outdoor uses is fast becoming more common. Despite all advantages of rainwater harvesting, we should consider some cramp factors such as physical, chemical and biological specifications of rain water.

TDS (total dissolved solids) is one of the physicochemical parameters which play an important role in water quality evaluation process. "Dissolved solids" refer to any minerals, salts, metals, cations or anions dissolved in water. TDS range in water supplies differ from $50 \mathrm{MgL}^{-1}$ in some surface water to more than $1000 \mathrm{MgL}^{-1}$ in ground water and mineral springs near volcanic mountain [3, 4]. The EPA Secondary Regulations advise a maximum contamination level (MCL) of $500 \mathrm{MgL}^{-1}$ (500 parts per million (PPM)) for TDS. Low TDS water is defined as that containing between 1 and 100 milligrams per liter $\left(\mathrm{MgL}^{-1}\right)$ of TDS. Rainwater is categorized as low TDS water which contains (0-20) $\mathrm{MgL}^{-1} \mathrm{TDS}$.

Most of the consumer complaints refer to water taste which is caused by high TDS. Not only does high TDS have an effect on water attributes like the taste but also low TDS content may have some medical side effect toward water consumers. A world health organization published a report which indicates that fluid and electrolytes of the human body are better replaced with water containing a minimum of $100 \mathrm{mg} / \mathrm{L}$ of TDS [5]. But this may depend on the situation and health level of the human body. In 1992 the Science Advisory Committee of Water Quality Association published a report about consumption of low TDS water and the possibility of some long terms potential harm which affect human health and life, but the exact effect would not be obvious until now.

Although highly purified (distilled) water is believed by some to help cure arthritis by washing out excess calcium and other minerals from deposits in joints, but they can leach minerals from body and thus cause disturbance in bodies [6].

Mixing rainwater with water from other resources in order to obtain water with optimum rate of TDS and achieving the optimum ratio of mixing are the mains scope of this research. 


\section{Material and methods}

\subsection{Study area}

Golestan is one the northern provinces in Iran with an area of approximately $21000 \mathrm{~km}^{2}$. Lack of water resources is the most significant dilemma in some parts of this area. Samples were taken from three villages in north of Golestan province near the Turkmenistan borderline (Klije, Tangali and Arabjigh located between $55^{\circ} 3^{\prime}$ north and $33^{\circ} 51^{\prime}$ east) as shown in Fig. 1 . The area population is about 500 and the average amount of rain in the research area is about 220 $\mathrm{mm} / \mathrm{yr}$. This area is categorized as hot hemisphere region. More than $75 \%$ of inhabitants utilize rain water as their water supply.

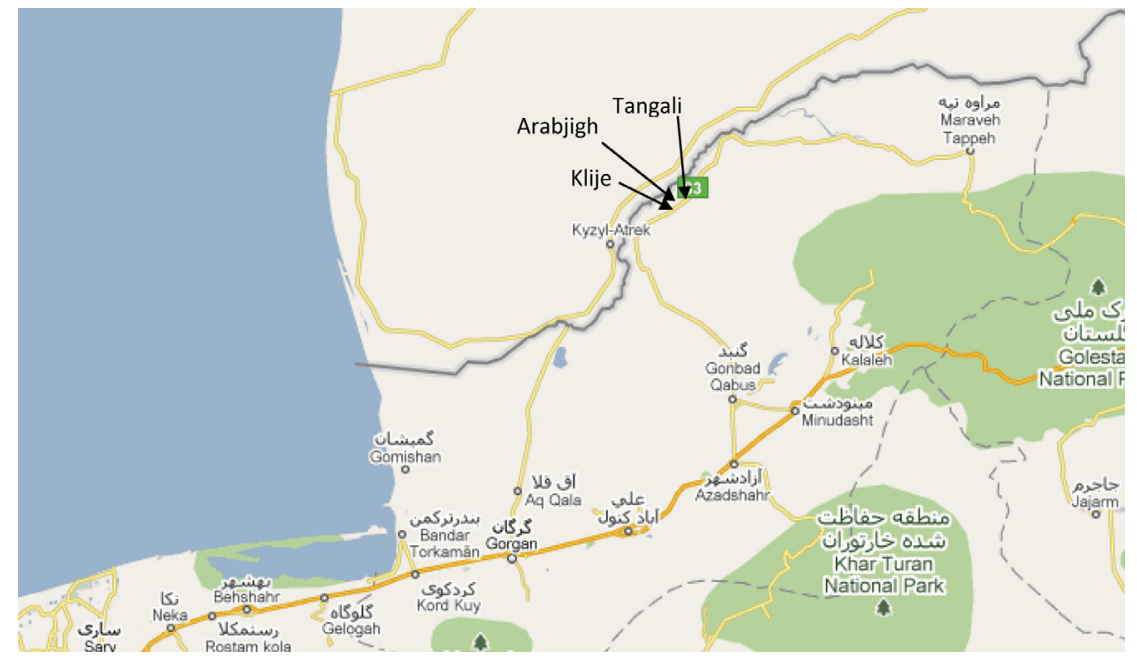

Figure 1: $\quad$ Map of study area in the north of Iran (Golestan province).

\subsection{Data collection}

The first stage of research was collecting information by a questionnaire from the inhabitant of the village about acceptability of rainwater. After it was clarified that more than 85 percent of inhabitants were dissatisfied with water quality, in the next stage samples of rain water were grabbed from water storage basin directly connected to the house roof and open areas near villages. These samples were taken at 4 periods of times (immediately; 6 hours; 12 hours; 1 day after rain) during 4 seasons of the year. Totally, 100 samples were collected from the study area in each season and analyzed to obtain TDS and TH levels. Also samples of surface water were taken from the Atrak River and groundwater samples from the nearest water well in the area. Samples of rain water were mixed with surface and groundwater and were analyzed to determine final amount of parameters. Hanna Multiparameter GPS Enabled Water Quality Meter portable kit was utilized for TDS measurement, TH test were fulfilled by titration with EDTA [7]. 


\section{Results}

Results of rainwater TDS and TH are presented in Figs. 2 to 7 and discussed below. As shown in Fig. 2 TDS of rainwater was differed from (2-15) $\mathrm{MgL}^{-1}$ with the mean of $8.2 \mathrm{MgL}^{-1}$ during seasons over the year. The maximum amount is $15 \mathrm{mg} / \mathrm{L}$ in April 2010 and the least one is about $2 \mathrm{MgL}^{-1}$ in January 2010 . Mean of TDS for rainwater in summer 2009 is $7 \mathrm{MgL}^{-1}(1.83$ as SD), in fall 2009 is $10 \mathrm{MgL}^{-1}$ (1.69 as SD), in winter 2010 is $2 \mathrm{MgL}^{-1}\left(1.04\right.$ as SD) and $15 \mathrm{MgL}^{-1}$ (2.23 as SD) in spring 2010. It seems that there is a correlation between rainwater TDS and atmosphere quality in study area, but that should be studied more in future research. TDS of surface water also fluctuated from (200-300) $\mathrm{MgL}^{-1}$ whereas this amount is about (540-600) $\mathrm{MgL}^{-1}$ for groundwater.

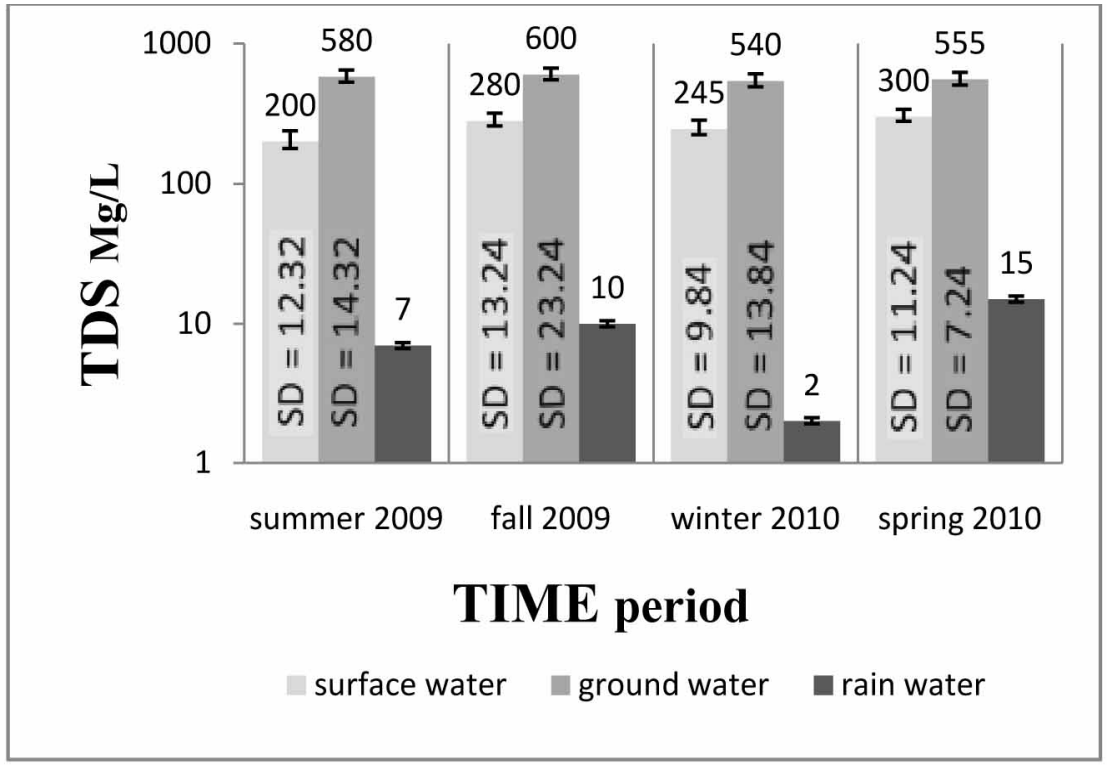

Figure 2: TDS rate in surface water, groundwater and rainwater during different seasons of the year 2009-2010.

After samples were mixed with surface and groundwater with 3 ratio as mentioned in Figs. 3 and 4, these results were gained: by utilizing 1/10 ratio of mixing with surface water TDS of rainwater modified up to $63 \mathrm{MgL}^{-1}$ (5.87 as SD) for spring 2010 samples, this amount for $2 / 10$ ratio is about $94 \mathrm{MgL}^{-1}$ (4.67 as SD) again in spring 2010 and for $3 / 10$ ratio is $105 \mathrm{MgL}^{-1}$ (7.75 as SD) in fall 2009 . For $1 / 10$ mixing ratio of rainwater with groundwater, TDS of rainwater modified up to $136 \mathrm{MgL}^{-1}$ (10.23 as SD ) as a mean of 100 samples in summer 2010, this amount for $2 / 10$ ratio is about $159 \mathrm{MgL}^{-1}$ (12.36 as SD) in fall 2009 and for 3/10 ratio is $163 \mathrm{MgL}^{-1}$ (9.31 as SD ) further in fall 2009 . 


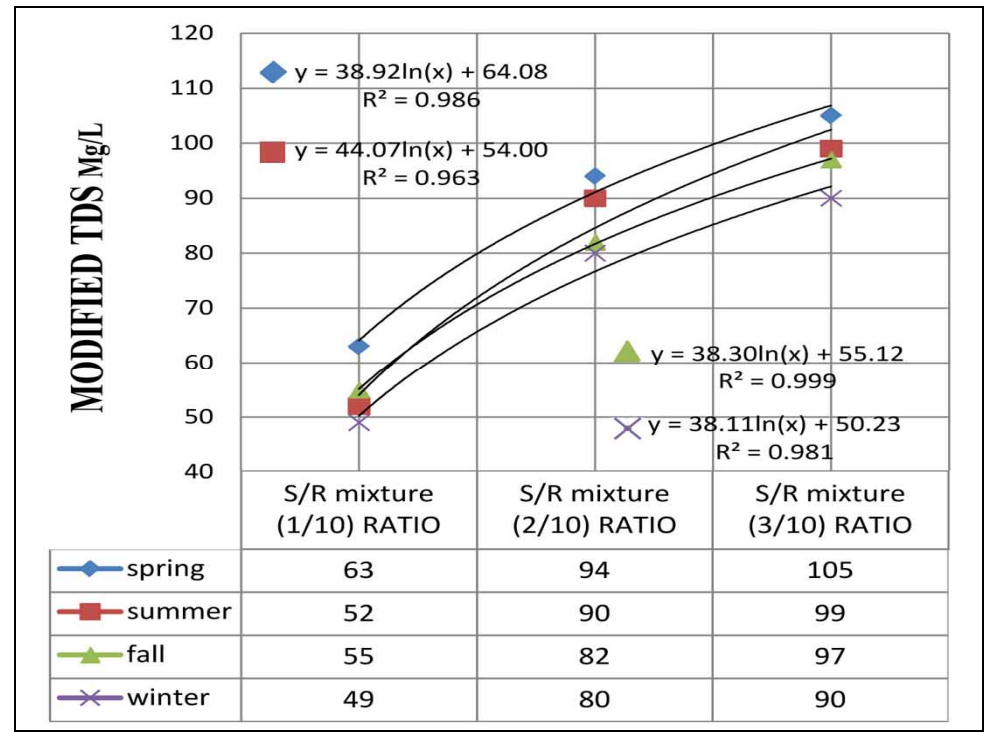

Figure 3: $\quad$ TDS of rainwater after mixing with surface water.

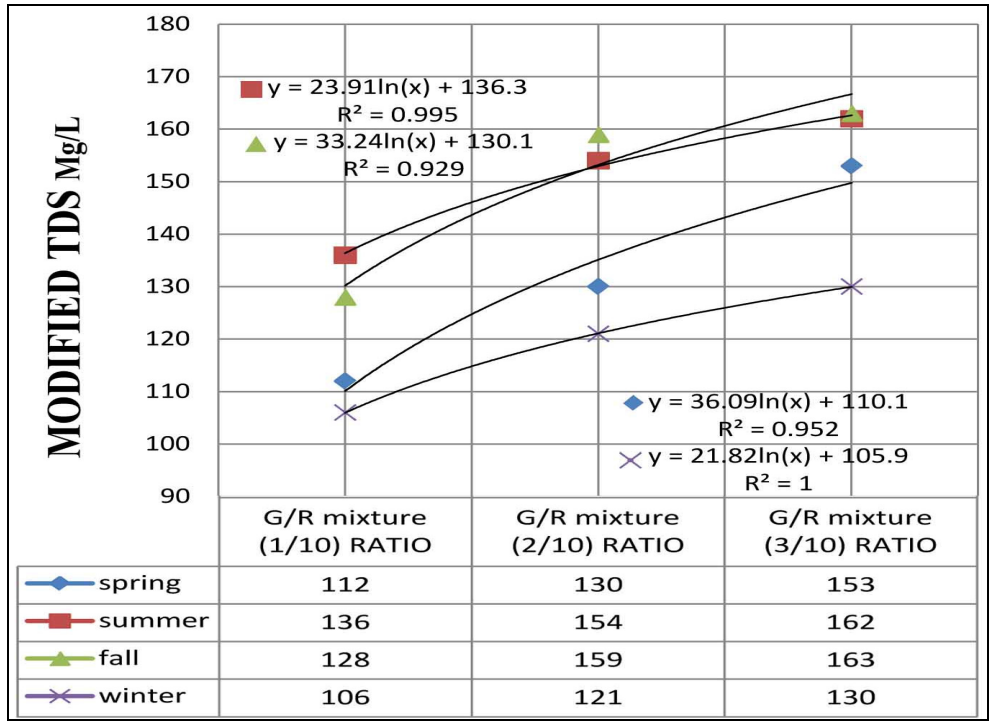

Figure 4: $\quad$ TDS of rainwater after mixing with ground water.

The second goal of this research was modifying rainwater TH. The mean value of rainwater $\mathrm{TH}$ is about $7 \mathrm{MgL}^{-1} \mathrm{Caco}_{3}$ (2.2 as SD) in summer 2009, 3 $\mathrm{MgL}^{-1} \mathrm{Caco}_{3}\left(1.2\right.$ as SD) in fall $2009,7 \mathrm{MgL}^{-1} \mathrm{Caco}_{3}(2.0$ as SD) in winter 2010 and $2 \mathrm{MgL}^{-1} \mathrm{Caco}_{3}(0.9$ as SD) in spring 2010. Fig. 5 indicates the primitive amount of $\mathrm{TH}$ in water from different resources near study area. 


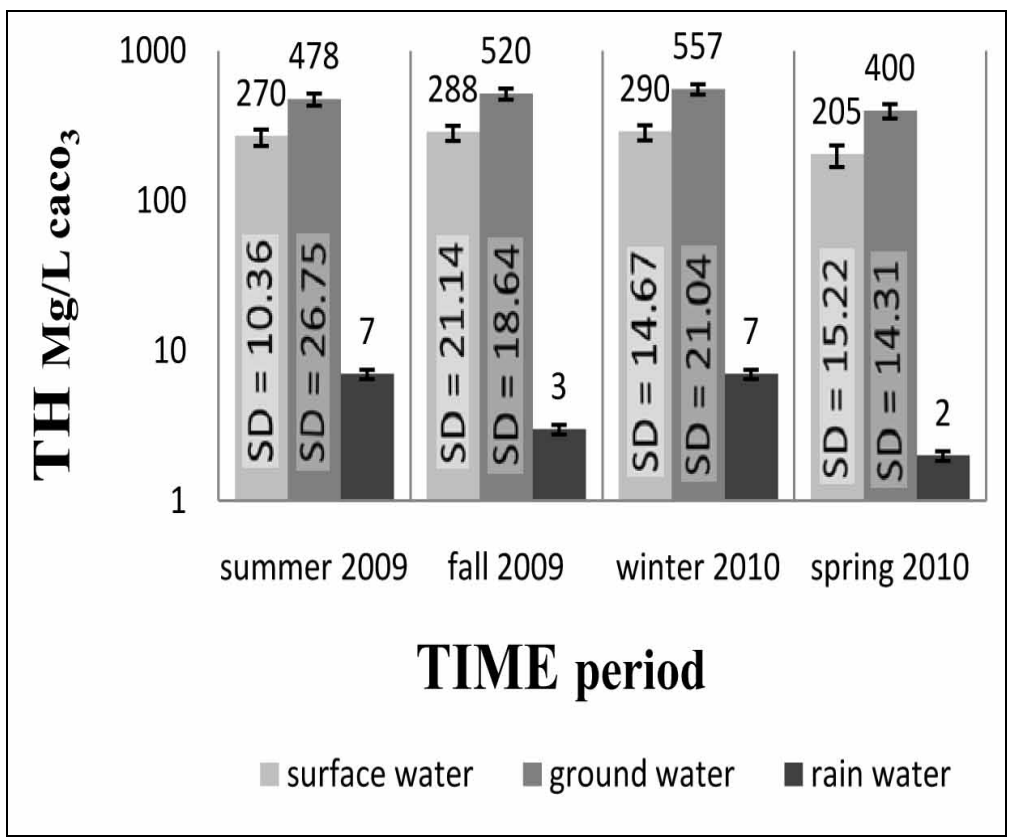

Figure 5: $\mathrm{TH}$ rate in surface water, groundwater and rainwater during different season of year 2009-2010.

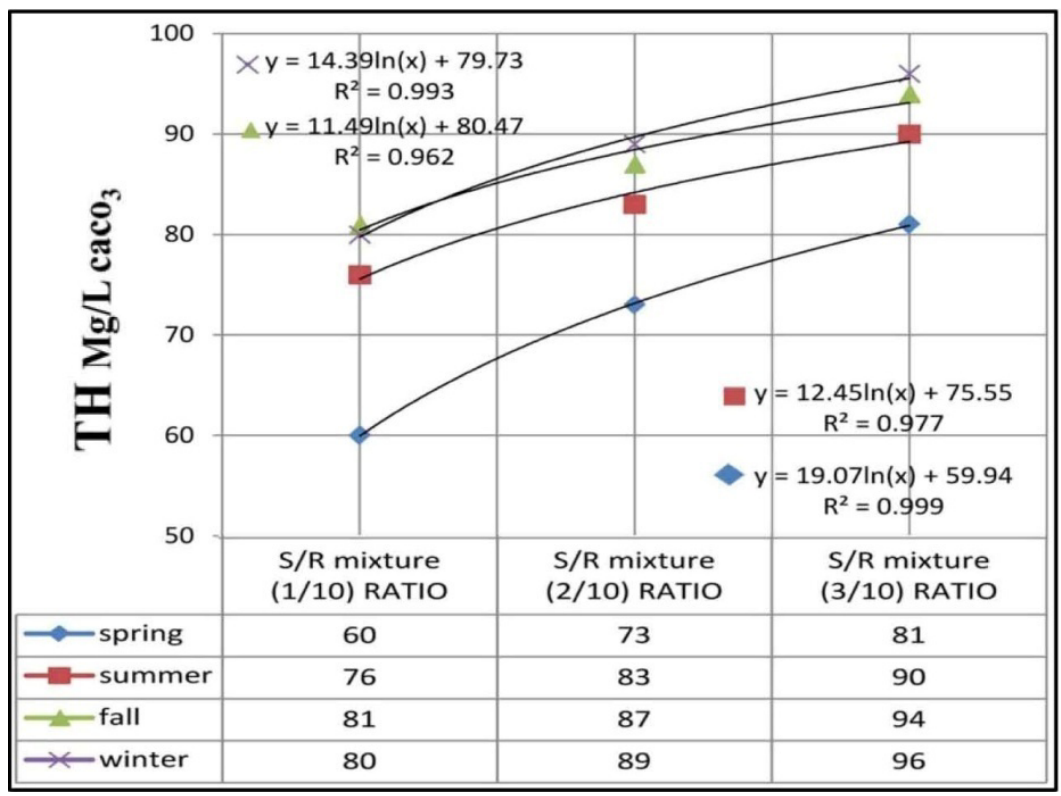

Figure 6: $\quad$ TH of rainwater after mixing with surface water. 


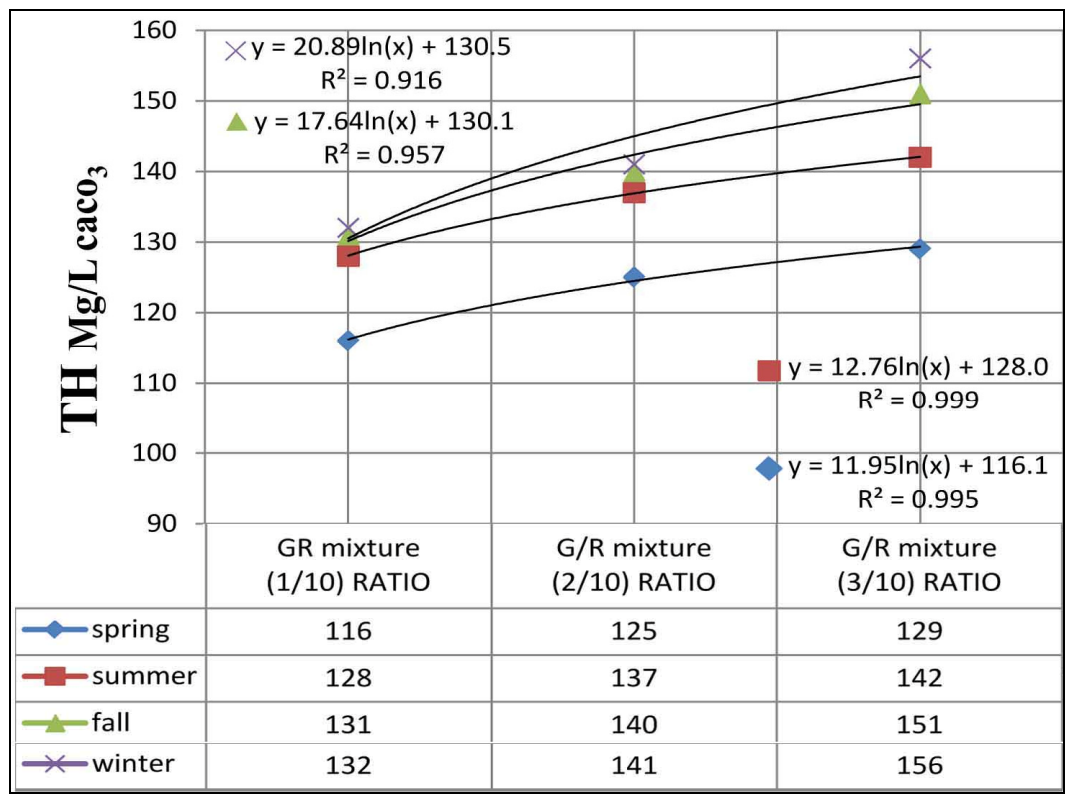

Figure 7: $\quad \mathrm{TH}$ of rainwater after mixing with ground water.

Samples of rainwater were mixed with surface water and groundwater samples to obtain ultimate amount of modified $\mathrm{TH}$ of rain water after mixing process. The first stage of $\mathrm{TH}$ modification test was mixing rainwater with surface water, during this test $\mathrm{TH}$ of rain water samples were modified up to 81 $\mathrm{MgL}^{-1} \mathrm{Caco}_{3}$ (6.82 as SD) in fall 2009 by utilizing $1 / 10$ ratio of mixing, this amount for $2 / 10$ ratio was changed to $89 \mathrm{MgL}^{-1} \mathrm{caco}_{3}$ (5.26 as SD) in 2010 winter and $96 \mathrm{MgL}^{-1} \mathrm{Caco}_{3}$ (4.72 as SD) during winter 2010 by utilizing 3/10 ratio of mixing. By the next step rainwater samples were mixed with groundwater samples. By utilizing 1/10 ratio of mixing $\mathrm{TH}$ amount of rainwater was modified up to $132 \mathrm{MgL}^{-1} \mathrm{Caco}_{3}$ (5.37 as SD) during winter 2010, whereas this amount for $2 / 10$ ratio is about $141 \mathrm{MgL}^{-1} \mathrm{caco}_{3}(8.62$ as SD) again in winter 2010 and finally rainwater $\mathrm{TH}$ was modified to $156 \mathrm{MgL}^{-1} \mathrm{caco}_{3}$ (4.85 as SD) in winter 2010.

\section{Discussion}

According to the obtained results of TDS and TH in this study, there are two significant factors which play an important role in choosing optimum mixing ratio. The first one is availability of water resources, due to the lack of sustainable water resources around the study area. Finding appropriate and acceptable resources of a water supply is difficult. The second dilemma which has an effect on making decision about mixing ratio is efficiency of each method. In fact these two factors mentioned above should be considered to be able to make decisions about the final result. 
After testing and determination of final TDS and TH value, the diagrams of TDS and TH against mixing ratio were plotted. After statistical and mathematical model analysis to determine the trend of TDS and TH modification during these tests, lines equation were calculated in the above charts with $95 \%$ confidence limit. Preparing water with a tolerable quality from surface or ground water resource is not so easy particularly in the summer, but also there is a need of treatment especially for surface water until the quality of water reach the accepted standard by government and inhabitants of villages. By utilizing 2/10 mixing ratio and consider the point that drinking and cooking water demand in hot seasons of the year especially in July and August is about 20Lday ${ }^{-1}$, therefore people can prepare $2 / 10$ of $20 \mathrm{~L}$ easily from water wells around their villages. For higher mixing ratio although rainwater TDS could be modified up to higher proportion, but provision of water supply is the main problem. Hygiene and health of water resources should be considered strictly because access to clean water is a basic human right, In India, one person dies from water-related disease every minute and four people die across the globe (EPA 2008) [8]. In the end it should noted that instructions to inhabitants of villages about how to mix water with rainwater in order to prevent sanitary problems is so important.

\section{References}

[1] Efe S. I., Quality of rainwater harvesting for rural communities of Delta State, Nigeria. Environmentalist, 26, pp. 175-181, 2006.

[2] Salem, V.A. Adrienne, L.a. Branche, H.O. Wack, D. Crawford, N. Sojka, Cabell Brand Center. Virginia Rainwater Harvesting Manual [Brochure]. pp. 4-8, 2007.

[3] UNEP. 2008, Water Quality for Ecosystem and Human Health. Second Edition.from:http://www.gemswater.org/publication/pdfs/water_quality_hu man_health.pdf.

[4] C. Tang, Water Quality Study and Cost-Benefit Analysis of Rainwater Harvesting in Kuttanad, India. Submitted in partial fulfillment of the Bachelor of Science Degree with Honors in Environmental Science from the Center of Environmental Studies at Brown University, 2009.

[5] WHO. 2006, Guidelines for Drinking-water Quality, First Addendum to ThirdEdition,Volume1Recommendations.From:http:/www.who.int/water_s anitation_health/dwq/gdwq3rev/en/.

[6] L.T. Rozelle, R.L. Wathen, consumption of low TDS water, A committee report by water quality association science advisory committee 1992-1993.

[7] S. L. Clescerl, A. E. Greenberg, A. D. Eato, Standard Methods for Examination of Water \& Wastewater (Standard Methods for the Examination of Water and Wastewater) American Public Health Association.

[8] http://water.epa.gov/lawsregs/rulesregs/sdwa/lt2/upload/2006_03_17 disinfection_lt2_assessment_lt2_occurance_main.pdf. 